\title{
A Study on Management Efficiency of Korean Ship Component Part Manufacturers
}

\author{
Myung-Jae Kim* \\ * Division of Maritime Transportation System, Mokpo Maritime University, Mokpo, 530, Korea
}

\begin{abstract}
This paper analyzes the efficiency of Korean Ship Component Part Manufacturer firms using DEA model. We evaluated the CCR, BCC efficiency and RTS of 30 Korea Ship Component Part Manufacturer firms. We also suggested the Korean Ship Component Part Manufacturer firms that can be benchmarked based on analyzed information. The result showed five enterprises whose values of CCR efficiency are 1, and eleven enterprises whose values of BCC efficiency are 1. RTS indicated IRS of 1 firms, DRS of 24 firms and CRS of 5 firms.
\end{abstract}

Key words : DEA, Ship Component Parts Manufacturers, efficiency, BCC-model, CCR-model

\section{Introduction}

The recent change of business environment introduces prompt products and services and enhances the quality to go with the trend of dealing with the technological opportunities. The product life cycle is getting shorter and as we are entering a competitive period of globalization, the management of manufacturing of ships, airplanes, electricity, automobiles, and computers is accelerating and is becoming more important.

Especially, there is a need for a check whether the strategic and result-oriented management of the ship component part manufacturing related to the ship industry is accomplishing efficient management.

Because ship component part manufacturing has experienced many changes in the process or parts, it has a different nature compared to other manufacturers. Because the equipments of ships are large-scale and the ship building process goes through many steps, there is a limit on automated production. So the relative importance of ship component parts manufacturing is growing. Currently, Korea's ship component part manufacturing has advanced in quality along with the growth of domestic shipbuilding yards and is being reorganized as a high-growth manufacturing industry even in quality.

Shipbuilding apparatus is named for all the machinery and materials used in the building and maintenance of ships and although there are differences according to the type and size of the ship, there are about 460 types. This takes up about 55 to $65 \%$ of the ship building costs. The domestic ship building apparatus industry is in a close relationship with the development process of the shipbuilding industry. Until the 1970s, the ship building industry was at a level that enabled the building of ships of less than 10,000 tons but thanks to the governmental policy of promoting heavy chemical industry, the shipbuilding industry started its full-fledged participation in the world-wide competition. In the 1970s, although building large ships, the ship building apparatus was in a poor state in terms of its business value due to the high barrier of the world-wide market and the function and quality that fell behind.

However, entering the 1980s, the outward appearance of the shipbuilding industry grew rapidly and while the government pushed ahead the localization efforts of the shipbuilding apparatus along with its technological development efforts on the overall industry, new businesses related to shipbuilding apparatus were being born and the ship loaded portion increased so that the amount of production continued its growth (refer to Table 1.)

Table 1 Domestic production of ship building apparatus in 2004-2008 (unit : 100 million won)

\begin{tabular}{|c|c|c|c|c|c|}
\hline Year & 2004 & 2005 & 2006 & 2007 & 2008 \\
\hline Production & 49,570 & 62,573 & 76,543 & 97,546 & 120,000 \\
\hline
\end{tabular}

Source : Korea Marine Equipment Association

However, the world-wide financial crisis of 2008 brought about a decrease in the amount of trade transaction between countries and as the shipping economy became stagnant and the shipbuilding industries that have enjoyed the booming economy before faced management crises due to the

* mjkim8060@hanmail.net 010)7549-1802 
decrease in the number of orders. Because of this, shipbuilding apparatus businesses have faced serial difficulty in their management as well.

Domestic ship building apparatus businesses are mostly small to midium-sized and are paying very high labor costs compared to the nearby countries, such as China, and is investing huge amounts of capital to secure the facilities, such as land for plants. Despite the high investments, however, because of a slump in sales, the return on the invested capital is not so high (Lee, 2004).

The purpose of this research is to analyze the amount sales on invested capital and to reach financial management efficiency that is related to the factors causing such difficulties for the domestic shipbuilding apparatus businesses.

For the purpose of the research as mentioned above, we seek to compare the management performance by measuring the efficiency of domestic ship component part manufacturing, which uses the DEA model that is used for the management efficiency analysis in regular manufacturing businesses. Through the DEA analysis, we provide information on the financial results for the efficiency of ship component part manufacturing by providing the projected value of businesses for an inefficient business to become more efficient and measure the efficiency of domestic ship component part manufacturing and proposes a referential set of inefficient businesses for an efficient benchmarking.

The composition of the study is as follows. First of all, we examine the shipbuilding industry, related to the domestic ship component part manufacturing and select an input variable and an output variable for the analysis on efficiency in terms of the present operational performance of domestic shipbuilding component part manufacturing, so that we can perform empirical studies on the efficiency of domestic ship component part manufacturing. Lastly, we seek to propose the implication of this research and the direction of later researches in the conclusion.

\section{Consideration of previous studies}

In this research, DEA-model, an analysis model used often in general manufacturing was used which eliminated any preceding studies in the ship industry. However, there are similar researches such as researches on the development situation of shipbuilding industry and an analysis on the actual conditions and on the growth of shipbuilding and material industry(Woo, 2003; Kim, 2008; Kim, 2005), the standardization and the direction of development of shipbuilding and material (Cha, 2009), an analysis on the actual conditions and the direction of development of shipbuilding and material (Lee, 2004), and the current situation of shipbuilding and material engineering (Hwang, 2002).

Thus, there were no studies on the analysis of management efficiency of ship component part manufacturing that can serve as a stepping stone in the ship industry.

Researches using the DEA model on the field of marine industry are as follows. There are those such as An Empirical Study on the Efficiency of Major Container Ports with DEA Model (Song \& Sin, 2005), Efficiency Measurement of Container Terminal in Korea Using DEA (Ryoo, 2005), A Study on the Efficiency Analysis of Korean Container Terminal (Park, Choi, Song \& Ryoo, 2007) and A Study on the New DEA Ranking Measurement for the Efficient Seaports based on Changing the Reference Set(Park, 2007).

In preceding researches, the efficiency of the port operations was mostly studied and for the input and output variables, mostly similar items were selected. Number of employees, length of the port, land area, Gantry Crance, number of cranes, and CFS area were chosen as the input variables and Yearly Container Throughout was chosen as the output variable.

Even in the preceding researches as mentioned above, we can see that a high portion of labor costs is accounted for in the port operation efficiency by selecting the number of labor as the input variable. Also in this research, we selected the labor power as the input variable in this perspective and used capital, sales and operating income that can affect the financial management efficiency as the analytic variables.

\section{Domestic shipbuilding industry and ship component part manufacturers}

While shipbuilding has high impacts on the front and the back industries since the demands for raw materials like steel and other related parts are wide--spread, it is an industry with a huge employment effect. Recently, because of the long recession in the shipbuilding industry, small and medium ship component part manufacturers are put on an emergency alert. The amount of delivered goods decreased and the unit price of the delivered goods were reduced up to $30 \%$, so in the cities with many ship parts equipment corporations like Busan and Geojae, 'June Crisis theory' are 
openly going around. When there was no sign of the industry getting better, the lands for the plants were given up in large amounts (Hankyung, 2010). Ship component parts greatly affect the shipbuilding industry. The shipbuilding industry can be seen as one in which the materials needed for ship building are all found to be in all fields of manufacturing such as machinery, metal, steel, chemicals, electricity, electronics and are demanded all around in the finished products and the half-finished products of each material.

Also, the shipbuilding industry has a limited automation of the heavy structures and therefore, is considered a labor-intensive industry and a technology-intensive industry because it requires high production technology. Thus, not only the man power is needed in the shipbuilding industry which leads the enhancement of technology across the industry in general, but also the employment effects extended from ship component part manufacturers are also significant as well. Unlike the shipbuilding industries of the past where there were only small demands, the present global trade volume has increased and as ships have become bigger and faster because of the rapid developments of shipbuilding technology, the number of the new orders from the ship owners have increased regardless of the cycle of shipbuilding industry. The important value of economically producing and the technology stands out also in the ship component part manufacturers related to the shipbuilding industry.

Also, it is possible to obtain a market share in a short period of time when the competitiveness is assured since the ship market is a single market. And because it is a product in which the import regulations of importing countries are small, a positive effect can be brought on to the management of ship component part manufacturing by a strategic prospective product aiming for exports. Unlike the industries dependent on domestic consumption, domestic shipbuilding industry has procured competitiveness in the global market environment and has been acknowledged for the global quality and technological ability and therefore, is the representative export industry with competitiveness which ranks first or second place in the world.

Thus, because the ripple effect of related industries is significant, not only the front industry but also the back industry greatly affects the machinery, the steel, the electricity, the electronics, and the chemicals.

It has been reported that the shipbuilding yards overseas that are the global ship manufacturing bases of the shipbuilding industry have taken a leap into the global ranking of shipbuilding yards based on the amount of the received orders.

According to Clarkson, a British shipbuilding and shipping analysis institution, the remaining amount of obtained orders of STX, Dalian, and DSME's manufacturing base was 76 ships and 1.502 million CGT ranking in 18th place in the world. This shows a leap of 2 steps from the 20th place (85 ships, 1.691 million CGT) in the beginning of the year and can be evaluated as having successfully positioned itself in the global shipbuilding market. STX Jinhae shipbuilding yard, a domestic corporation, is ranked at the 4th place in the world with 168 ships and a remaining amount of obtained orders of 4.768 million CGT after Hyundai Heavy Industries Co., Ltd. (Ulsan), Samsung Heavy Industries Co., Ltd. (Geoje), and DSME (Mokpo). The STX Dalian DSME manufacturing base is a total shipbuilding yard built by STX group in Changxing Island, Dalian city, Liaoning, China with the total area of 0.55 million square meters (approximately 0.17 million Pyeong). It is equipped with a locally complete manufacturing system from processing the basic materials, such as casting and forging, to engine assembly and block production. This shipbuilding yard started full-scale operation by steel cutting for the production of ship block in April of 2008, and it positioned itself in an axis of the global manufacturing network of STX by successfully delivering 2 bulk ships of 58 thousand DWT. Subic shipbuilding yard in the Philippines, a global manufacturing base of Hanjin Heavy Industries and Construction Co., Ltd., ranked 20th place for the first time. The remaining amount of obtained orders of Subic shipbuilding yard was 43 ships and 1.491 million CGT last year with the year-end ranking of 19th, 3 steps up from 22nd place in the beginning of the year. Youngdo shipbuilding yard, a domestic corporation, maintained the 23rd place with 45 ships and a remaining amount of obtained orders of 1.324 million CGT.

Table 2 Order account by overseas korean shipyard in 2009

\begin{tabular}{|c|c|c|c|}
\hline \multirow{2}{*}{ Shipyard } & \multicolumn{2}{|c|}{ Orderbook } & \multirow{2}{*}{ World Rank } \\
\cline { 2 - 3 } & Quantity & CGT(Ton) & \\
\hline STX Dalian & 76 & $150.2 \mathrm{mil}$ & 18 \\
\hline STX Jinhae & 168 & $476.8 \mathrm{mil}$ & 4 \\
\hline Hanjin Subic & 43 & $149.1 \mathrm{mil}$ & 19 \\
\hline Hanjin Pusan & 45 & $132.4 \mathrm{mil}$ & 23 \\
\hline
\end{tabular}

Source : Clockson's World ship Orderbook 2010

Currently, the competition in the shipbuilding industry to win the contracts of minor ship owners is heating up. 
According to the Clarkson report, despite the fact that the order situation is improving, the ship price index based on last month's end was 136.1 point where it had been decreasing continuously for 16 months and had hit a record low after July of 2004. In the midst of it all, it is meaningful to note that the changing orders of domestic shipbuilding industry are continuing since the end of 2009. Korean shipbuilding industry obtained orders for 16 ships (1.72 million DWT) of the 34 ships that were newly contracted last month and had recorded a market share of $56.7 \%$, surpassing China (6 ships, 0.253 million DWT, 13.2\%). Korea is also expected to raise the share of remaining amount of obtained orders per country to $34.2 \%$ (1830 ships, 171.1 million DWT) and surpass China of 34.4\% (3113 ships, 187.3 million DWT) and return as 1st place in the world (Asia Economy, 2010).

Table 3 World ship order by Korea \& China in May 2010

\begin{tabular}{|c|c|c|c|}
\hline \multirow{2}{*}{ Country } & \multicolumn{2}{|c|}{ Ship Order } & Market share \\
\cline { 2 - 3 } & Quantity & DWT & $(\%)$ \\
\hline Korea & 16 & $1.72 \mathrm{mil}$ & 56.7 \\
\hline China & 6 & $0.253 \mathrm{mil}$ & 13.2 \\
\hline
\end{tabular}

Source: Asia Economic Daily in March, 2010

Table 4 World order account by Korea \& China in May, 2010

\begin{tabular}{|c|c|c|c|}
\hline \multirow{2}{*}{ Country } & \multicolumn{2}{|c|}{ World Order Account } & Market share \\
\cline { 2 - 3 } & Quantity & DWT & $(\%)$ \\
\hline Korea & 1830 & $171.1 \mathrm{mil}$ & 34.2 \\
\hline China & 3113 & $187.3 \mathrm{mil}$ & 34.4 \\
\hline
\end{tabular}

Source : Asia Economic Daily in March, 2010

\section{DEA Model}

The measurement of efficiency of corporations can be seen as an index in which each corporation is relatively evaluated based on the most efficient corporation. DEA is a method that evaluates the relative efficiency among the institutions with similar forms of input and output (Charnes et al., 1978). DEA is separated into input-oriented model and output-oriented model according to the mathematical method of getting the optimal solution. Input-oriented model has to evaluate to what extent the input and cost can be minimized while maintaining the level of output steadily. On the other hand, output-oriented model is interested in to what extent the output needs to be achieved when a certain level of input is given, or the output maximization (Banxia Software,
2003).

After the CCR-model was presented, various DEA-models were proposed (Cooper et al. 2004). These models hold different assumptions especially on disposability, convexity, and return to scale which are normally allowed in the producible sets. The CCR-model assumes strong disposability on producible set, convexity of the set, and constant returns to scale. Other DEA models also assume the convexity of producible sets and it is normal for them to assume strong disposability but differs greatly in terms of return to scale. Return to scale means the reaction of output when all of the input factors are proportionately increased. CCR model assumes a constant return to scale which states that output also increases steadily. Some economists assume an S-shaped production function which exhibits increasing returns to scale when the size of input is small and goes through the stage of constant returns to scale as the input size increases and finally has the characteristic of showing decreasing returns to scale. In the case of BCC model which is widely used along with CCR, the two assumptions mentioned previously are the same as the CCR model. However, it assumes a variable return to scale in terms of return to scale (Banker et al. 1996). By using the two models of CCR and BCC, we can produce three types of efficiency.

\section{CCR model: Technical and Scale Efficiency (TSE) \\ BCC model: Technical Efficiency (TE) \\ CCR / BCC: Scale Efficiency (SE)}

\section{Study on management efficiency of ship component part manufacturers}

\subsection{Selection of input and output, collection of data}

DEA indicates the relative efficiency of each DMU in figures and suggests the potential improvement for each variable. So there is an advantage in being able to develop a management strategy in improving the efficiency of the corporations using this. Thus, we seek to apply it to analyze the relative efficiency of ship component part manufacturing. Because there were not many studies that analyzed the ship component part manufacturers using DEA, overall, variables used generally in measuring the efficiency of corporations were selected.

In this research, the equity and the number of employees were selected as the input variable for the analysis of the management efficiency of the domestic ship component part manufacturers and the sales and operational income were 
selected as the output variables.

The number of the employees and equity, or the input variables are the variables that show the size of the ship component part manufacturing corporations. We are to examine the efficiency between the size and the performance of the ship component part manufacturers. For the output variables, the sales and the operational profits were chosen since they are the most important performance variable in the evaluation of the business management. We seek to examine the management efficiency through the relative efficiency of domestic ship component part manufacturing based on each selected variable and for the convenience of the analysis, the variables were controlled and classified as follows.

Table 5 Operational definitions of variables

\begin{tabular}{|c|c|c|}
\hline $\begin{array}{c}\text { Name of } \\
\text { variable }\end{array}$ & Operational definition & $\begin{array}{c}\text { Classification } \\
\text { of variables }\end{array}$ \\
\cline { 1 - 2 } $\mathrm{x} 1$ & Capital & \multirow{2}{*}{ Input variable } \\
\hline $\mathrm{x} 2$ & Number of employee & \multirow{2}{*}{ Output variable } \\
\hline $\mathrm{y} 1$ & Sales & \\
\hline $\mathrm{y} 2$ & Operating Income & \\
\hline
\end{tabular}

The data for analysis on the performance evaluation of the domestic ship component part manufacturers were collected through the Korchambiz site (www. korchambiz.net). The range of the ship component part manufacturing was limited to the ship component part manufacturers with sales within the top 30 in 2008. The descriptive statistics of input variables for the performance evaluation of the 30 selected ship component part manufacturers in the research is shown in Table 6. The unit of number of employees is the number of people and the equity, the sales, and the operational profits are in 100 million won. From this table, you can tell that there is a considerable difference in the size of input and output of the domestic ship component part manufacturers that are the object of research.

Table 6 Statistics on input/output data

\begin{tabular}{|c|c|c|c|c|}
\hline Value & Equity & $\begin{array}{c}\text { Number of } \\
\text { employees }\end{array}$ & Sales & $\begin{array}{c}\text { Operating } \\
\text { Profit }\end{array}$ \\
\hline $\begin{array}{c}\text { maximum } \\
\text { value }\end{array}$ & 5488 & 800 & 10262 & 1662 \\
\hline $\begin{array}{c}\text { minimum } \\
\text { value }\end{array}$ & 37 & 24 & 525 & -23 \\
\hline average & 605 & 243 & 1668 & 184 \\
\hline $\begin{array}{c}\text { standard } \\
\text { deviation }\end{array}$ & 1067 & 207 & 2401 & 307 \\
\hline
\end{tabular}

\subsection{Analysis on efficiency using DEA}

Of the DEA models, CCR-I model and BCC-I model were used in this research in order to evaluate the operational efficiency of domestic ship component part manufacturing (Cooper et al., 2006). Also, in order to identify the ranking among the efficient businesses, SUPER-CRR-I model and the SUPER-BCC-I model were used. As explained in the preceding paragraph, the result of the efficiency value, ranking, and returns to scale (RTS) in 2008 of each corporation using the collected financial data of 30 ship component part manufacturers are as shown in Table 7. In 2008, there were 5 corporations with CCR efficiency of 1 . There were 11 corporations that were efficient in BCC efficiency. It was identified that corporations with CCR efficiency of 1 also had a scale efficiency of 1 . The corporations were efficiently managed and were shown to be properly using the scale. However, although the BCC efficiency is 1 for STX Heavy Industries Co., Ltd., Sungdong Shipbuilding \& Marine Engineering Co., Ltd., Sejin Heavy Industries Co., Ltd., Shinhan Machinery Co., Ltd., Samwoo Memcor Co., Ltd., and Kangrim Insulation Co., Ltd., the scale efficiency for each is $0.648,0.733,0.824,0.599$, 0.908 , so in terms of scale effect they are being efficiently managed. However, in situations where the scale effect is steady inefficiency is exhibited. This can be seen as being in an unfavorable situation due to the scale. On the other hand, although the value of the scale efficiency for Daeyang Electric Co., Ltd., BIP Industries Co., Ltd., Haedeok Electric Co., Ltd., Dai Han Anchor Chain MFG. Co., Ltd., Sunbo Industries Co., Ltd., Donglim Industrial Co., Ltd., Iljin Machinery Co., Ltd., Song Kang Heavy Industries Co., Ltd., Hyukshin Machinery Co., Ltd. is above 0.9 and thought to be managed inefficiently, it is interpreted that they are using the scale well despite the fact that the $\mathrm{CCR}$ and $\mathrm{BBC}$ efficiencies for those corporations were all below 0.5 .

In terms of returns to scale (RTS), there were 1 corporation with IRS, 24 corporations with DRS, and 5 corporations with CRS. It can be interpreted that the ship component part manufacturers with IRS were relatively small in size and can expect improvements in profitability through the increases in size. On the other hand, the ship component part manufacturers with DRS as the returns to scale are mostly corporations large in size where the improvement in the profitability through reduction of size is important. The ranking among the efficient shipping and logistics corporations are Staco Co., Ltd., WD Heavy Industries Co., Ltd., Buem Steel Co., Ltd., and Geochung Shipbuilding Co., Ltd. which are ranked at the first place in both CCR and BCC. 
Table 7 Results of efficiency

\begin{tabular}{|c|c|c|c|c|c|c|c|}
\hline \multirow{2}{*}{ No. } & \multirow{2}{*}{$\mathrm{DMU}$} & \multicolumn{5}{|c|}{ Efficiency } & \multirow{2}{*}{ RTS } \\
\hline & & $\mathrm{BCC}$ & Ranking & $\mathrm{CCR}$ & Ranking & SE & \\
\hline 1 & $\begin{array}{l}\text { STX Heavy } \\
\text { Industries Co., Ltd. }\end{array}$ & 1 & 1 & 0.648 & 12 & 0.648 & DRS \\
\hline 2 & $\begin{array}{l}\text { Sungdong } \\
\text { Shipbuilding \& } \\
\text { Marine Engineering } \\
\text { Co., Ltd. }\end{array}$ & 1 & 1 & 0.733 & 10 & 0.733 & DRS \\
\hline 3 & $\begin{array}{l}\text { Oriental Precision \& } \\
\text { Engineering Co., } \\
\text { Ltd. }\end{array}$ & 0.774 & 14 & 0.350 & 22 & 0.452 & DRS \\
\hline 4 & $\begin{array}{l}\text { Sejin Heavy } \\
\text { Industries Co., Ltd. }\end{array}$ & 1 & 1 & 0.824 & 8 & 0.824 & DRS \\
\hline 5 & $\begin{array}{l}\text { Shinhan Machinery } \\
\text { Co., Ltd. }\end{array}$ & 1 & 1 & 0.599 & 14 & 0.599 & DRS \\
\hline 6 & $\begin{array}{l}\text { Hochang Machinery } \\
\text { Industries Co., Ltd. }\end{array}$ & 0.854 & 13 & 0.667 & 11 & 0.781 & DRS \\
\hline 7 & $\begin{array}{l}\text { Lee Young Industrial } \\
\text { Machinery Co., Ltd. }\end{array}$ & 0.468 & 20 & 0.346 & 23 & 0.739 & DRS \\
\hline 8 & $\begin{array}{l}\text { Imcheon Industries } \\
\text { Co., Ltd. }\end{array}$ & 0.526 & 17 & 0.459 & 17 & 0.873 & DRS \\
\hline 9 & Staco Co., Ltd. & 1 & 1 & 1 & 1 & 1 & CRS \\
\hline 10 & Cheonhaeji Co., Ltd. & 0.948 & 12 & 0.822 & 9 & 0.867 & DRS \\
\hline 11 & Samgong Co., Ltd. & 0.478 & 19 & 0.362 & 20 & 0.757 & DRS \\
\hline 12 & $\begin{array}{l}\text { Daeyang Electric Co., } \\
\text { Ltd. }\end{array}$ & 0.291 & 27 & 0.269 & 27 & 0.923 & DRS \\
\hline 13 & $\begin{array}{l}\text { Samwoo Memcor Co., } \\
\text { Ltd. }\end{array}$ & 1 & 1 & 0.908 & 7 & 0.908 & DRS \\
\hline 14 & Gwangsan Co., Ltd. & 0.289 & 28 & 0.253 & 28 & 0.877 & DRS \\
\hline 15 & $\begin{array}{l}\text { Daechang Metal Co., } \\
\text { Ltd. }\end{array}$ & 0.309 & 25 & 0.288 & 26 & 0.930 & DRS \\
\hline 16 & $\begin{array}{l}\text { Sunbo Unitech Co., } \\
\text { Ltd. }\end{array}$ & 0.689 & 15 & 0.635 & 13 & 0.921 & DRS \\
\hline 17 & $\begin{array}{l}\text { BIP Industries Co., } \\
\text { Ltd. }\end{array}$ & 0.316 & 24 & 0.300 & 24 & 0.948 & DRS \\
\hline 18 & $\begin{array}{l}\text { WD Heavy Industries } \\
\text { Co., Ltd. }\end{array}$ & 1 & 1 & 1 & 1 & 1 & CRS \\
\hline 19 & $\begin{array}{l}\text { Haedeok Electric Co., } \\
\text { Ltd. }\end{array}$ & 0.496 & 18 & 0.462 & 16 & 0.932 & DRS \\
\hline 20 & $\begin{array}{l}\text { Rolls-Royce Marine } \\
\text { Korea Co., Ltd. }\end{array}$ & 0.570 & 16 & 0.528 & 15 & 0.925 & DRS \\
\hline 21 & $\begin{array}{l}\text { Dong-a Industry Co., } \\
\text { Ltd. }\end{array}$ & 1 & 1 & 1 & 1 & 1 & CRS \\
\hline 22 & $\begin{array}{l}\text { Dai Han Anchor } \\
\text { Chain MFG. Co., Ltd. }\end{array}$ & 0.246 & 29 & 0.232 & 29 & 0.943 & IRS \\
\hline 23 & $\begin{array}{l}\text { Kangrim Insulation } \\
\text { Co., Ltd. }\end{array}$ & 1 & 1 & 0.922 & 6 & 0.922 & DRS \\
\hline 24 & $\begin{array}{l}\text { Sunbo Industries Co., } \\
\text { Ltd. }\end{array}$ & 0.155 & 30 & 0.154 & 30 & 0.997 & DRS \\
\hline 25 & Buem Steel Co., Ltd. & 1 & 1 & 1 & 1 & 1 & CRS \\
\hline 26 & $\begin{array}{l}\text { Donglim Industrial } \\
\text { Co., Ltd. }\end{array}$ & 0.463 & 21 & 0.443 & 18 & 0.957 & DRS \\
\hline 27 & $\begin{array}{l}\text { Iljin Machinery Co., } \\
\text { Ltd. }\end{array}$ & 0.359 & 23 & 0.357 & 21 & 0.995 & DRS \\
\hline 28 & $\begin{array}{l}\text { Song Kang Heavy } \\
\text { Industries Co., Ltd. }\end{array}$ & 0.372 & 22 & 0.371 & 19 & 0.997 & DRS \\
\hline 29 & $\begin{array}{l}\text { Hyukshin Machinery } \\
\text { Co., Ltd. }\end{array}$ & 0.301 & 26 & 0.298 & 25 & 0.989 & DRS \\
\hline 30 & $\begin{array}{l}\text { Geochung } \\
\text { Shipbuilding Co., Ltd. }\end{array}$ & 1 & 1 & 1 & 1 & 1 & CRS \\
\hline
\end{tabular}

The frequency of the referential set in this research is shown in Table 8 and Table 9 below. Beum Steel Co., Ltd. and Geochung Shipbuilding Co., Ltd. showed the highest frequency of referential set of 23 times and 12 times each in CCR and Sejin Heavy Industries Co., Ltd. and Beum Steel Co., Ltd. each showed a high frequency of 13 times in BCC and were the corporation that will be the object of the most benchmarking cases in terms of management efficiency of the domestic ship component part manufacturing in 2008.

Table 8 CCR-model frequency in reference set

\begin{tabular}{|l|c|}
\hline \multicolumn{1}{|c|}{$\begin{array}{c}\text { Referential corporation of } \\
\text { CCR-model }\end{array}$} & Frequency \\
\hline Staco Co., Ltd. & 9 \\
\hline WD Heavy Industries Co., Ltd. & 3 \\
\hline Dong-a Industry Co., Ltd. & 3 \\
\hline Beum Steel Co., Ltd. & 23 \\
\hline Geochung Shipbuilding Co., Ltd. & 12 \\
\hline
\end{tabular}

Table 9 BCC-model frequency in reference set

\begin{tabular}{|l|c|}
\hline \multicolumn{1}{|c|}{$\begin{array}{c}\text { Referential corporation of } \\
\text { BCC-model }\end{array}$} & Frequency \\
\hline STX Heavy Industries Co., Ltd. & 1 \\
\hline $\begin{array}{l}\text { Sungdong Shipbuilding \& Marine } \\
\text { Engineering Co., Ltd. }\end{array}$ & 2 \\
\hline Sejin Heavy Industries Co., Ltd. & 13 \\
\hline Shinhan Machinery Co., Ltd. & 1 \\
\hline Staco Co., Ltd. & 8 \\
\hline Samwoo Memcor Co., Ltd. & 2 \\
\hline WD Heavy Industries Co., Ltd. & 7 \\
\hline Dong-a Industry Co., Ltd. & 2 \\
\hline Kangrim Insulation Co., Ltd. & 10 \\
\hline Beum Steel Co., Ltd. & 13 \\
\hline
\end{tabular}

In this research, if there is an inefficient corporation among the shipping and logistics corporations, the figures for the efficiency of the corporations are provided by suggesting the projected value of the values that each corporation has to improve. It would be easy to improve the efficiency of the corporations if each shipping and logistics corporation knew the projected value when projecting on the efficient frontier. As a typical corporation where the efficiency value is greater than 0.5 of domestic ship component part manufacturers, we will examine Oriental Precision \& Engineering Co., Ltd., Hochang Machinery Industries Co., Ltd., Imcheon Industries Co., Ltd., Sunbo Unitech Co., Ltd., and Rolls-Royce Marine Korea Co., Ltd. 
The results on the projected values are as shown in Table 10 .

Table 10 Results of projection

\begin{tabular}{|c|c|c|c|c|}
\hline $\begin{array}{c}\mathrm{DMU} \\
\mathrm{I} / \mathrm{O}\end{array}$ & $\begin{array}{l}\text { Score } \\
\text { Data }\end{array}$ & Projection & Difference & $\%$ \\
\hline $\begin{array}{l}\text { Oriental Precision \& } \\
\text { Engineering Co., } \\
\text { Ltd. }\end{array}$ & 0.774 & & & \\
\hline Equity & 1196 & 925.922 & -270.077 & $-22.58 \%$ \\
\hline Number of employees & 663 & 455.458 & -207.541 & $-31.30 \%$ \\
\hline Sales & 3959 & 3959 & 0 & $0.00 \%$ \\
\hline Operating Profit & 330 & 330 & 0 & $0.00 \%$ \\
\hline $\begin{array}{l}\text { Hochang Machinery } \\
\text { Industries Co., Ltd. }\end{array}$ & 0.854 & & & \\
\hline Equity & 556 & 475 & -81 & $-14.57 \%$ \\
\hline Number of employees & 520 & 320.666 & -199.333 & $-38.33 \%$ \\
\hline Sales & 2088 & 2445.583 & 357.583 & $17.13 \%$ \\
\hline Operating Profit & 316 & 316 & 0 & $0.00 \%$ \\
\hline $\begin{array}{l}\text { Imcheon Industries } \\
\text { Co., Ltd. }\end{array}$ & 0.526 & & & \\
\hline Equity & 742 & 390.419 & -351.580 & $-47.38 \%$ \\
\hline Number of employees & 254 & 133.647636 & -120.352 & $-47.38 \%$ \\
\hline Sales & 1185 & 1311.648 & 126.648 & $10.69 \%$ \\
\hline Operating Profit & 234 & 234 & 0 & $0.00 \%$ \\
\hline $\begin{array}{l}\text { Sunbo Unitech Co., } \\
\text { Ltd. }\end{array}$ & 0.689 & & & \\
\hline Equity & 211 & 145.410 & -65.589 & $-31.09 \%$ \\
\hline Number of employees & 67 & 46.173 & -20.826 & $-31.09 \%$ \\
\hline Sales & 742 & 742 & 0 & $0.00 \%$ \\
\hline Operating Profit & 90 & 90 & 0 & $0.00 \%$ \\
\hline $\begin{array}{l}\text { Rolls-Royce Marine } \\
\text { Korea Co., Ltd. }\end{array}$ & 0.570 & & & \\
\hline Equity & 105 & 59.873 & -45.126 & $-42.98 \%$ \\
\hline Number of employees & 95 & 54.171 & -40.828 & $-42.98 \%$ \\
\hline Sales & 649 & 649 & 0 & $0.00 \%$ \\
\hline Operating Profit & 40 & 40 & 0 & $0.00 \%$ \\
\hline
\end{tabular}

Looking at the projected value for efficiency, if Oriental Precision \& Engineering Co., Ltd. reduces its inputs of equity to $22.58 \%$ and the number of employees to $31.30 \%$, it can reach the efficient frontier. Also, Hochang Machinery Industries Co., Ltd. needs to reduce its inputs of equity to $14.57 \%$ and the number of employees to $38.3 \%$ and increase sales to $17.13 \%$ for the improvement on efficiency to reach the efficient frontier. Imcheon Industries Co., Ltd. needs to reduce $47.38 \%$ of equity and $31.09 \%$ of the number of employees and increase the sales to $10.69 \%$ in order to reach the efficient frontier. Sunbo Unitech Co., Ltd. needs to reduce $31.09 \%$ of equity and $46.98 \%$ of number of employees. Rolls-Royce Marine Korea Co., Ltd. can reach the efficient frontier if it reduces $42.98 \%$ of the equity and $42.98 \%$ of the number of employees. This projected value shows a relative value compared to other shipping and logistics corporation so if the variable that affects the efficiency of domestic ship component part manufacturing is known precisely and if the focus is put on the improvement of management of the corporation, it will contribute greatly to the performance as well as the efficiency. Fig. 1 and Fig. 2 shown below are the graphs of BCC-efficiency of ship component part manufacturing. The vertical axis of the graph shows the figures of efficiency measurement and the horizontal axis shows the DMU of domestic ship component part manufacturers. It is possible to confirm that the efficiency measurements are shown to be 1 for shipping and logistics corporations on the efficient frontier.

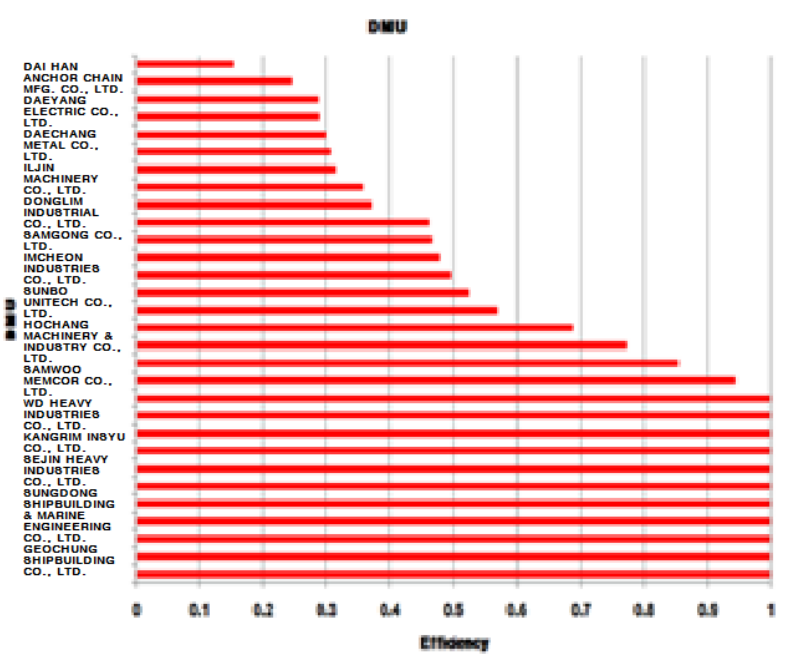

Fig. 1 Graph of efficiency

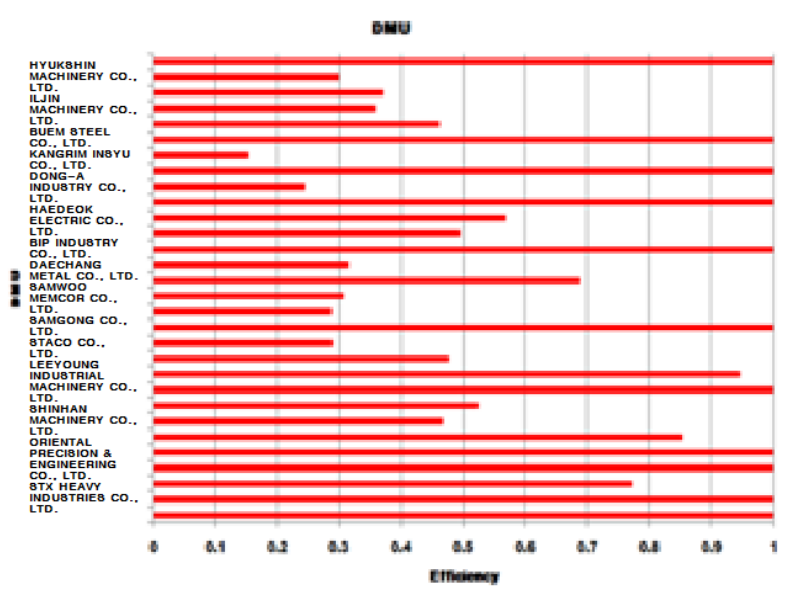

Fig. 2 Graph of efficiency

\section{Conclusion}

This research analyzed the management efficiency by applying it to domestic ship component part manufacturing 
through the DEA-model. The DEA-model, used for the measurement of efficiency of businesses, is used widely because the multiple inputs and outputs can be applied. In this research, various DEA-models were applied to evaluate the efficiency of domestic ship component part manufacturing in 2008. First of all, Super-Efficiency model was introduced to verify the rankings of the CCR-model and the BCC-model. The summary of the essential analyzed results are as follows. In the total of 30 domestic ship component part manufacturers, 5 were those with CCR-efficiency of 1 and 11 were those with BCC-efficiency of 1 . In terms of returns to scale, the studies showed 1 corporation, Dai Han Anchor Chain MFG, Co., Ltd with IRS of 1 for IRS, 24 corporations for DRS, and 5 corporations for CRS. In the results above, as we can verify that corporations with CCR efficiency of 1 also had scale efficiency of 1 , it is interpreted that these corporations are efficiently operated in an adequate size.

However, STX Heavy Industries Co., Ltd, Sungdong Shipbuilding \& Marine Engineering Co., Ltd, Sejin Heavy Industries Co., Ltd, Shinhan Machinery Co., Ltd, Samwoo Memcor Co., Ltd, Kangrim Insulation Co., Ltd had BCC efficiency of 1 but the scale efficiency did not follow such figures so when the effects of scale are not constant, inefficiency is shown and thus indicates a need for an adequate supervision.

On the other hand, although Daeyang Electric Co., Ltd, BIP Industries Co., Ltd, Haedeok Electric Co., Ltd, Dai Han Anchor Chain MFG, Co., Ltd, Sunbo Industries Co., Ltd, Donglim Industrial Co., Ltd, Iljin Machinery Co., Ltd, Song Kanng Heavy Industries Co., Ltd, Hyukshin Machinery Co., Ltd had low CRR and BBC efficiency, the value of scale efficiency was shown to be high. So despite the inefficient operation, it was shown to maintain an adequate size.

In terms of return to scale (RTS), there was 1 corporation with IRS, 24 corporations with DRS, and 5 corporations with CRS. The corporations with return to scale of IRS were comparatively small in size, so it can be interpreted as they can expect an improvement in profitability through an increase in size. On the other hand, the corporations with return to scale of DRS were mostly large-sized corporations, which shows that they should aim for an improvement in profitability by decreasing their size. Ranking among efficient corporations were Staco Co., Ltd, WD Heavy Industries Co., Ltd, Dong-a Industry Co., Ltd, Beum Steel Co., Ltd, Geochung Shipbuilding Co., Ltd and these corporations are all ranked 1st place in CCR and BCC.

Efficient corporations with high referential frequency were
Beum Steel, Co., Ltd, Geochung Shipbuilding Co., Ltd, and Sejin Heavy Industries Co., Ltd. Benchmarking these corporations will be help the inefficient corporations to increase its efficiency and improve the management environment.

The limitations of this research and potential later research problems are as follows.

First, the current research analyzed the efficiency of DEA based on the domestic ship component part manufacturers that ranked within the top 30 places in terms of sales in 2008 so it was confined to the static analysis. There was the limitation of not being able to perform a dynamic analysis of the ship component part manufacturers because the rankings in terms of sales of ship component part manufacturers varied every year. In the later researches, a dynamic analysis using DEA/WINDOW Malmquist analysis should be performed.

Second, the research only presents the variables that are to be improved on the inefficient DMU and fails to provide a detailed plan for the improvement. The selected input and output variables for the study on the efficiency of the ship component part manufacturers were financial. It is thought that the empirical analysis using a more specific variable of each ship component part manufacturer is needed in later studies on efficiency.

\section{References}

[1] Asia Economic Daily (2010, 3.1), "Instability in Market Conditions, the Opening of a 'Winner-Take-All' Era?".

[2] Banker, R. D., Chang, H. and Cooper, W. W.(1996), "Simulation Studies of Efficiency, Returns to Scale and Misspecification with Nonlinear Functions in DEA", Annals of Operations Research, Vol. 66, pp. 233-253.

[3] Banxia Software(2003), Banxia Frontier Analyst User's Guide. UK: Banxia Software Limited.

[4] Cha, J. H.(2009), "The Standardization and the direction of Development of Shipbuilding and Material", The Society of Naval Architects of Korea, Vol.46, No.2, pp.3-9.

[5] Charnes, A., Cooper, W. W. and Rhodes, E.(1978), "Measuring the Efficiency of Decision Making Units", European Journal of Operational Research, Vol. 2, pp. 429-444.

[6] Cooper, W. W., Seiford, L. M., Tone, K.(2006), Introduction to Data Envelopment Analysis and DEA-Solver Software and References, Springer.

[7] Cooper, W. W., Seiford,L. M., Thanassoulis, E. and 
Zanakis, S. H.(2004), "DEA and Its Use in Different countries", European Journal of Operational Research, Vol. 154, pp. 337-344.

[8] EBN Industry News(2010, 1.13), "One Step 'UP' for the Status of Korean Shipbuilding in the World".

[9] Hwang, K. H.(2002), "The Current Situation of Shipbuilding and Material Engineering", The Society of Naval Architects of Korea, Vol.39, No.3, pp.16-29.

[10] Kim, K. M.(2005), "Current State and Problem of Domestic Shipbuilding and Material Industry; Development of Fundamental Technology is the Task for Both the People and the Government", Monthly Maritime Korea, Vol. 2005, No. 5, pp. 40-41.

[11] Kim, J. H.(2008), "Current State of High Value Shipbuilding and Material Industry and Direction for Development", The Korean Institute of Power Electronics Journal, Vol. 13, No. 5, pp. 47-51.

[12] Lee, S. T.(2004), "An Analysis on the actual Conditions and the Direction of development of Shipbuilding and Material", The Society of Naval Architects of Korea, Vol.41, No.1, pp.33-47.

[13] Moon, Y. K.(2006), "Current State and Understanding of Korea's Shipbuilding Industry in the Perspective of Competitive Strategy", Sea Korea, Vol. 2006, No. 7, pp. 181-204.

[14] Porter, M. E.(1996), "What is Strategy?", Havard Business Review, November-December.

[15] Park B. K., Choi M. S., Song J. Y. and Ryoo D. K. "A Study on the Efficiency Analysis of Korean Container Terminal", Journal of Korean Navigation and Port Research, Vol.31, No.1, pp.89-96.

[16] Park N. K.(2007), "A Study on the New DEA Ranking Measurement for the Efficient Seaports based on Changing the Reference Set", Journal of Korean Navigation and Port Research", Vol.31, No.5, pp.403-408.

[17] Ryoo D. K.(2005), "Efficiency Measurement of Container Terminal in Korea Using DEA", The Journal of Shipping and Logistics", Vol.47, pp.21-38.

[18] Song J. Y. and Sin C. H.(2005)“ An Empirical Study on the Efficiency of Major Container Ports with DEA Model", Journal of Korean Navigation and Port Research, Vol.29, No.3, pp.195-201.

[19] Woo, Y. S.(2003), "Growth of Korean ShipbuildingRelated Industry and Regional Agreement", The Korean Association of Regional Geographers Journal, Vol. 9,
No. 1, pp. 53-65.

[20] www. Korchambiz.net

Received 30 July 2010

Revised 21 September 2010

Accepted 24 September 2010 